\title{
Myxomycetes developed on grain in moist chamber cultures
}

\author{
MARJA HÄRKÖNEN and HILKKA KOPONEN
}

HÄRKÖNEN, M. and KOPONEN, H. 1978: Myxomycetes developed on grain in moist chamber cultures. - Karstenia 18: 58-62.

Cereal seeds from 16 localities in Finland were grown in 1480 moist chamber cultures. Six species of Myxomycetes emerged. Three are new to Finland: Didymium comatum (A. Lister) Nann.-Brem., D. cf. dubium Rost. and D. iridis (Ditmar) Fries. The others are: Physarum apiculosporum Härkönen, Didymium difforme (Pers.) S.F.Gray and D. squamulosum (Alb. \& Schw.) Fries. The assortment of species is smaller and differs distinctly from that emerging on bark from living trees in moist chambers.

Myxomycetous spores are more resistant to drying than those of the other fungi on grain. On the other hand, slime moulds develop most oten in the same dishes where the other fungi are most abundant.

Marja Härkönen, Department of Botany, University of Helsinki, Unioninkatu 44, SF00170 Helsinki 17, Finland

Hilkka Koponen, Agricultural Research Centre, Institute of Plant Pathology, SF01300 Vantaa 30, Finland

\section{Material and methods}

The material consisted of seed samples sent to the Institute of Plant Pathology in autumn 1976 by 16 Experiment Stations of the Agricultural Research Centre, from the following localities:

V: 1. Mietoinen; U: 2. Vantaa, 3. Anjalankoski; St: 4. Kokemäki, 5. Mouhijärvi; EH: 6. Jokioinen, 7. Pälkäne; ES: 8. Mikkeli rural commune; EP: 9. Ylistaro; PH: 10. Laukaa; PS: 11. Maaninka; PK: 12. Tohmajärvi; KP: 13. Toholampi; Kn. 14. Vaala; PP: 15. Ruukki, 16. Rovaniemi rural commune.

Of the 296 seed samples examined, 155 belonged to Hordeum vulgare, 102 to Avena sativa, 16 to Secale cereale and 23 to Triticum aestivum. There were two groups of samples: the first taken directly from the fields after harvesting, the second dried in grain dryers. The samples were kept in $1 / 2 \mathrm{~kg}$ paper bags in room temperature. The fresh material was examined within 3 months, the dried grain after about $5-7$ months.

The cereal seeds were examined by the second author, using a modification of the blotter test (de Tempe 1963). Seeds selected at random were placed in moist chambers made from glass Petri dishes $(\varnothing 15 \mathrm{~cm}$ ), on two filter papers laid on cellulose and wetted with distilled water (about 25 $\mathrm{ml}$ ). Twenty seeds were put into each Petri dish. The distance between each seed was at least $2 \mathrm{~cm}$. From every sample 100 seeds $(5 \times 20)$ were examined. The seeds were kept 2 weeks at about $15^{\circ} \mathrm{C}$ and then examined for the first time. The sprouts were cut to facilitate microscopic examination. The seeds were then kept 2 weeks at room temperature (about $+20-24^{\circ} \mathrm{C}$ ), and checked for fungi again. All the Myxomycetes that emerged were taken aside and sent to the first author. For the results concerning true fungi, see Ylimäki et al. (1978).
The Myxomycetes were identified with the aid of the following literature: Lister (1925), Martin \& Alexopoulos (1969), Nannenga-Bremekamp (1974). The earlier Scandinavian records were checked from Bjørnekaer \& Klinge (1963), Blytt (1892), Eliasson (1975), Eliasson \& Strid (1976), Eliasson \& Sunhede (1972), Härkönen (1974, 1977, 1978a), Karlsen (1934, 1943), Lister (1911), Santesson (1964). Representative specimens of the species found are deposited in $\mathrm{H}$ and the private collection of Dr. N.E. Nannenga-Bremekamp in Doorwerth, the Netherlands.

\section{The species of Myxomycetes}

The numbers in parentheses refer to the collecting sites of the seed samples. $\mathrm{A}=$ Avena, $\mathrm{H}=$ Hordeum, $\mathrm{S}=$ Secale, $\mathrm{T}=$ Triticum $. \mathrm{F}=$ fresh, $\mathrm{D}$ $=$ dried grains.

\section{Physarum apiculosporum Härkönen}

One ex. from locality 14 on dried seeds of $\mathrm{H}$. This newly described species (Härkönen 1978b) has been reported only from Finland.

Since the description, the species has been cultivated to the fifth generation. The sporophores grew smaller from generation to generation, possibly owing to a shortage of food, since nothing was added to the moist chambers except Avena seeds and distilled water. The spores also became smaller, being $8-8.9-9.5 \times 10-10.9-12 \mu \mathrm{m}$ in the fourth generation, as against $8-9.1-10 \times 10-11.8-14$ 
$\mu \mathrm{m}$ in the original description. The width-to-length ratio also changed slightly, approximately from 0.77 to 0.82 . The bright dark brown colour, smooth surface and the apiculus of the spores remained constant.

All the plasmodia stayed small, but were otherwise typical phaneroplasmodia (Gray \& Alexopoulos 1968). Their colour varied widely from colourless to bright orange even in the same culture. The most actively moving plasmodia were always colourless. It was easy to follow the protoplasmic streaming because the plasmodia ingested spores of the same species and the dark spores then moved back and forth inside the veins of the plasmodia. The rhythm of movement was very changeable, and the spores went irregularly to different veins of plasmodium in the successive streaming periods.

Didymium comatum (A. Lister) Nann.-Brem.

Five exx. from four localities $(6,7,10,15)$; A 3, H 2; F 2, D 3. Distributed at least in Japan, Holland and the U.S.A. (Nannenga-Bremekamp 1966). Not reported from Scandinavia. New to Finland.

Sporangia pulvinate to short plasmodiocarpous, depressed, $0.1-1.2 \mathrm{~mm}$ in diam. Peridium double: the outer part smooth, eggshell-like, white, made of sharp stellate lime crystals, absent from some sporangia; the inner part dark, membranous, iridescent. Hypothallus narrow, yellowish or absent. No columella, but base white, rugose. Capillitium very abundant, not dividing, light brown. Spores dark brown in mass, violaceous grey in transmitted light, finely warted, $8.5-9.7-11.5 \mu \mathrm{m}$.

The sporophores have a superficial recemblance to those of $D$. difforme, but $D$. comatum is clearly distinguished by the abundant capillitium, and spores of different size, colour and ornamentation (lacking the dark branching lines) (Fig. 1). Dr. N.E. Nannenga-Bremekamp has seen some of the specimens and identified them as $D$. comatum. The spore size given in her description of the species (Nannenga-Bremekamp 1966), 10-13 $\mu \mathrm{m}$, is larger than in the specimens; on the other hand, according to Lister (1901) the spores are smaller and paler than those of $D$. difforme (Fig. 2).

\section{Didymium difforme (Pers.) S.F. Gray}

142 exx. from all the collecting sites except No. 8. A 77, H 52 , S 10 , T 3 . F 50 , D 92 . Widely distributed. Reported from all Fennoscandian countries.

From pulvinate sporangia to flat, netted or effused plasmodiocarps, $0.2-6.5 \mathrm{~mm}$ in diam. Peridium double: the outer smooth, eggshell-like, white, or greyish white, composed of lime crystals; the inner membranous, delicate, greyish, purplish or colourless

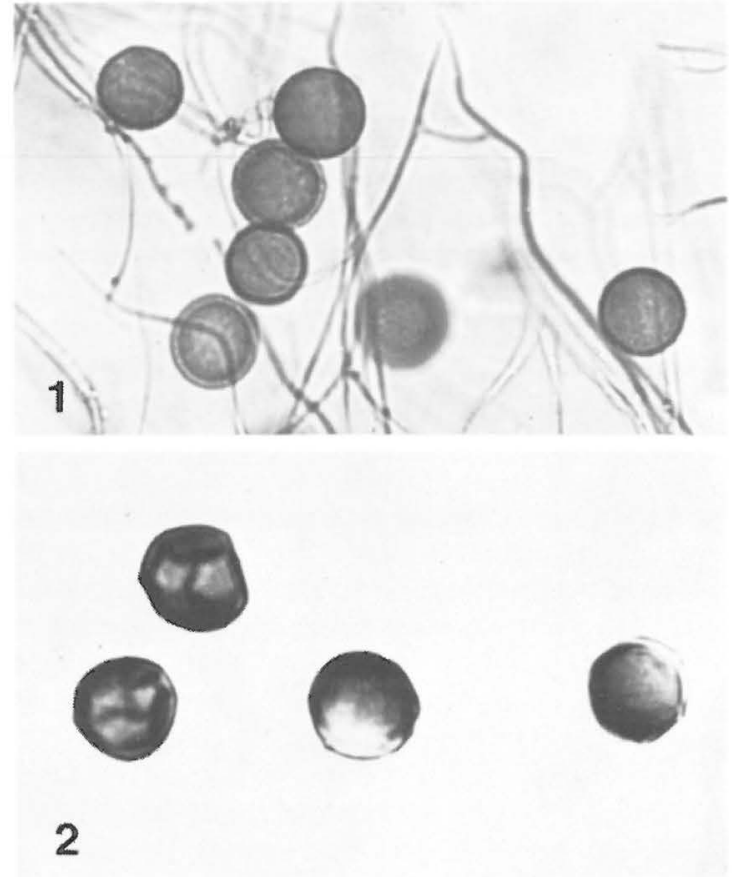

Figs. 1-2. Spores of Didymium species, X 900. - 1: D. comatum (No. 1147), - 2: D. difforme (No. 1078).

at top, yellowish at base, iridescent. In some sporangia the outer peridium is present only on the top of the sporophore or is totally absent, the sporophore then being almost black. Sporophores surrounded by a narrow, transparent band of ochre or orange yellow hypothallus. No columella. Capillitium scanty, lightcoloured, slender. Spores black in mass, dark purple brown in transmitted light, minutely warted to nearly smooth and having a lighter edge and dark lines along which they are wrinkled (see Fig. 2) (they take a couple of hours in Hoyer's medium to swell and become globose), $11-12.2-14 \mu \mathrm{m}$.

Karsten (1876) reported this species from Finland, but Hintikka (1919), referred Karsten's specimens to Diderma globosum Pers. Failing to observe crystalline lime granules, Härkönen (1974) followed Hintikka's treatment. Now, having become more familiar with the species, she has learned that in some specimens in which the crust is compact and the crystals small, the crystalline structure is difficult to discern. However, it is usually possible to see the angular particles in the broken edge. Karsten's specimens were re-examined and found quite clearly to represent $D$. difforme, although the crystalline lime is not stellate. 
Didymium cf. dubium Rost.

10 exx. from four localities $(4,6,7,15)$. A 6, H 4. F 6, D 4. Recorded from Europe, the U.S.A., India, Japan (Emoto 1977), South America (Farr 1976). Reported from Sweden. New to Finland.

Flat plasmodiocarps about $0.4-2.2 \times 0.4-6 \mathrm{~mm}$ in diam. Some are grey having only membranous peridium, some are covered with small, slender, stellate lime crystals and some have a crustose, white outer wall of lime crystals. Hypothallus narrow, yellowish brown. No columella. Capillitium very scanty, pallid. Spores medium brown in mass, very minutely warted, light violaceous grey in transmitted light, $11-12.7-15 \mu \mathrm{m}$ in diam.

According to Martin \& Alexopoulos (1969), this species is characterized by the flat grey plasmodiocarps, small densely aggregated crystals and large $(10-15 \mu \mathrm{m})$, rather dark spores. The spores of the present specimens are large, but light. According to Kowalski (1975), the spores of $D$. dubium are purple brown in mass, minutely warted and usually $10-12 \mu \mathrm{m}$ in diam. He does not share the opinion of Martin \& Alexopoulos (1969) that $D$. nivicolum Meylan (a blackspored species) is synonymous with $D$. dubium. According to Emoto (1977), D. dubium has purple grey, spinulose or nearly smooth spores, whose diameter ranges as much as from 8 to $15 \mu \mathrm{m}$. This agrees well with the present specimens but not with the original description of Rostafiński (1875), where the spore size of $D$. dubium is only $10-10.8 \mu \mathrm{m}$. Nor does the very weak capillitium of our specimens agree completely with the description, though the nature of the peridium does. We have not been able to find the type specimen and so cannot be certain of the identification.

\section{D. iridis (Ditmar) Fr.}

Three exx. from two localities $(2,15)$. A 2, H 1. F 1, D 2. Cosmopolitan. Reported from Sweden and Denmark. New to Finland.

Sporangia globose, shallowly umbilicate, $0.3-0.5$ $\mathrm{mm}$ in diam. Total height $0.9-1.2 \mathrm{~mm}$. Peridium thin, membranous, grey, covered with white stellate lime crystals. Stalk striate, translucent, orangeochraceous. Hypothallus well developed, thin, discoid, concolorous with stalk. Columella white, with a subglobose head. Capillitium rather abundant, light brown at base, hyaline at tips. Spores sepia in mass, light violaceous grey in transmitted light, finely warted with clusters of bigger warts, 7-8.2-9.5 $\mu \mathrm{m}$.

The specimens fit the key of Nannenga-
Bremekamp (1972) well, the head of the white columella being globose and the stalk light ochraceous.

D. squamulosum (Alb. \& Schw.) Fr.

Five exx. from three localities $(9,12,15)$. A 4, S 1. F 1, D 4. Cosmopolitan.

\section{Discussion}

All the species of Myxomycetes that emerged belonged to the order Physarales, and all the specimens except one to the genus Didymium. This differs totally from the species composition of the Myxomycetes that developed on bark from living trees in moist chamber cultures made by the first author. Of the 700 specimens of Myxomycetes that emerged in 1547 moist chambers, only 13 (representing seven species) belonged to Physarales and none to Didymium. Brooks (1967) includes Didymium and Physarum in a list of taxa that are abundant and represented by large numbers of species on terrestrial substrata, but have only one or two species that are common on bark. NannengaBremekamp, however, writes (in litt.) that she has obtained the following Didymium species on bark in moist chambers: D. clavus (Alb. \& Schw.) Rab., D. dubium, D. squamulosum, D. sturgisii Hagelst. and $D$. difforme. Gilbert \& Martin (1933) report $D$. sturgisii (as D. anomalum Sturgis) and D. clavus from bark in moist chambers. Keller \& Braun (1977) report $D$. difforme in moist chambers on bark of Taxodium mucronatum Ten. Keller \& Brooks (1973) even describe two new species of Didymium which have been observed only on bark of red cedar. Mitchell (1977) reports $D$. iridis from elder bark in a moist chamber and Davis \& Butterfield (1967) from banana peel in a moist chamber.

None of the species observed by the first author in moist chambers with bark emerged on the cereal seeds (Härkönen 1977, 1978a) e. g. Echinostelium minutum de Bary, Arcyria cinerea (Bull.) Pers., A. pomiformis (Leers.) Rost., Comatricha nigra (Pers.) Schroet., Enerthenema papillatum (Pers.) Rost. Paradiacheopsis fimbriata (G. List. \& Gran) Hertel.

The amount of specimens obtained on grain is much smaller in relation to the number of moist chamber cultures prepared than the amount obtained on bark. The results are not, however, fully comparable, because the moist chamber cultures with bark were checked at least every second day and those with grain only twice during four weeks. 
Table 1. The occurrence of Eumycotina and Myxomycetes in different moist chamber cultures.

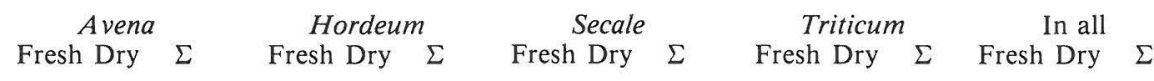

\begin{tabular}{|c|c|c|c|c|c|c|c|c|c|c|c|c|c|c|c|}
\hline $\begin{array}{l}\text { Total no. of } \\
\text { moist chambers }\end{array}$ & 255 & 255 & 510 & 275 & 500 & 775 & 40 & 40 & 80 & 60 & 55 & 115 & 630 & 850 & 1480 \\
\hline $\begin{array}{l}\text { With few fungi } \\
\text { as } \% 0\end{array}$ & $\begin{array}{l}5 \\
2\end{array}$ & $\begin{array}{l}45 \\
18\end{array}$ & $\begin{array}{l}50 \\
10\end{array}$ & $\begin{array}{r}25 \\
9\end{array}$ & $\begin{array}{r}315 \\
63\end{array}$ & $\begin{array}{r}340 \\
44\end{array}$ & $\begin{array}{r}5 \\
13\end{array}$ & $\begin{array}{l}20 \\
50\end{array}$ & $\begin{array}{l}25 \\
31\end{array}$ & $\begin{array}{l}10 \\
17\end{array}$ & $\begin{array}{l}10 \\
18\end{array}$ & $\begin{array}{l}20 \\
17\end{array}$ & $\begin{array}{r}45 \\
7\end{array}$ & $\begin{array}{r}390 \\
46\end{array}$ & $\begin{array}{r}435 \\
29\end{array}$ \\
\hline $\begin{array}{l}\text { With fairly many fungi } \\
\text { as } \%\end{array}$ & $\begin{array}{l}65 \\
26\end{array}$ & $\begin{array}{r}170 \\
67\end{array}$ & $\begin{array}{r}235 \\
46\end{array}$ & $\begin{array}{r}130 \\
47\end{array}$ & $\begin{array}{r}160 \\
32\end{array}$ & $\begin{array}{r}290 \\
37\end{array}$ & $\begin{array}{l}30 \\
75\end{array}$ & $\begin{array}{l}10 \\
25\end{array}$ & $\begin{array}{l}40 \\
50\end{array}$ & $\begin{array}{l}10 \\
17\end{array}$ & $\begin{array}{l}30 \\
55\end{array}$ & $\begin{array}{l}40 \\
35\end{array}$ & $\begin{array}{r}235 \\
37\end{array}$ & $\begin{array}{r}370 \\
44\end{array}$ & $\begin{array}{r}605 \\
41\end{array}$ \\
\hline $\begin{array}{l}\text { With many fungi } \\
\text { as } \%\end{array}$ & $\begin{array}{r}185 \\
73\end{array}$ & $\begin{array}{l}40 \\
16\end{array}$ & $\begin{array}{r}225 \\
44\end{array}$ & $\begin{array}{r}120 \\
44\end{array}$ & $\begin{array}{r}25 \\
5\end{array}$ & $\begin{array}{r}145 \\
19\end{array}$ & $\begin{array}{r}5 \\
13\end{array}$ & $\begin{array}{l}10 \\
25\end{array}$ & $\begin{array}{l}15 \\
19\end{array}$ & $\begin{array}{l}40 \\
67\end{array}$ & $\begin{array}{l}15 \\
27\end{array}$ & $\begin{array}{l}55 \\
48\end{array}$ & $\begin{array}{r}350 \\
56\end{array}$ & $\begin{array}{l}90 \\
11\end{array}$ & $\begin{array}{r}440 \\
30\end{array}$ \\
\hline $\begin{array}{l}\text { With Myxomycetes } \\
\text { as } \%\end{array}$ & $\begin{array}{l}27 \\
11\end{array}$ & $\begin{array}{l}65 \\
26\end{array}$ & $\begin{array}{l}92 \\
18\end{array}$ & $\begin{array}{l}29 \\
11\end{array}$ & $\begin{array}{r}31 \\
6\end{array}$ & $\begin{array}{r}50 \\
8\end{array}$ & $\begin{array}{r}6 \\
13\end{array}$ & $\begin{array}{r}6 \\
15\end{array}$ & $\begin{array}{l}11 \\
14\end{array}$ & $\begin{array}{l}1 \\
2\end{array}$ & $\begin{array}{l}2 \\
4\end{array}$ & $\begin{array}{l}3 \\
3\end{array}$ & $\begin{array}{l}62 \\
10\end{array}$ & $\begin{array}{r}104 \\
12\end{array}$ & $\begin{array}{r}166 \\
11\end{array}$ \\
\hline
\end{tabular}

Table 2. The numbers of Petri dishes with Myxomycetes in each abundance group.

$\begin{array}{lrcrr} & \begin{array}{c}\text { Few } \\ \text { fungi }\end{array} & \begin{array}{c}\text { Fairly many } \\ \text { fungi }\end{array} & \begin{array}{c}\text { Many } \\ \text { fungi }\end{array} & \begin{array}{r}\text { In } \\ \text { all }\end{array} \\ \text { Petri dishes } & 435 & 605 & 440 & 1480 \\ \text { with Myxomycetes } & 14 & 81 & 71 & 166 \\ \text { as \% } & 3 & 13 & 16 & 11\end{array}$

\section{The abundance of Myxomycetes compared with that of other fungi}

Table 1 shows the number of moist chambers made and the numbers of slime moulds and other fungi that developed in each group of the material. The Petri dishes were divided into three groups according to the numbers of Eumycotina:

1. Few fungi: Number of fungi species not more than two per seed.

2. Fairly many fungi: Number of fungi species two to three per seed.

3. Many fungi: Number of fungi species more than three per seed.

Drying the seeds evidently decreases the amount of Eumycotina, but not that of Myxomycetes. On the contrary, in most cases, there is a greater number of Myxomycetes on dried than on fresh grain. Myxomycetous spores are presumably more resistant to drying. It appears from Table 2 that the Myxomycetes do not suffer from competition by Eumycotina. In spite of the difference in their tolerance of dry conditions, the Myxomycetes most often tend to develop in the same dishes where the other fungi are most abundant.
Acknowledgements. - We want to thank Dr. N.E. Nannenga-Bremekamp for help in identifying difficult specimens and Dr. T. Niemelä for translating the Polish description of Didymium dubium.

\section{References}

Bjørnekaer, K. \& Klinge, A. 1963: Die dänishen Schleimpilze. Myxomycetes Daniae. - Friesia 7: 149-296.

Blytt, A. 1892: Bidrag til kundskaben om Norges soparter 3. Myxomyceter. - Videnskabs-Selskabs Forhandl., Christiania, 1892 (2): 1-13.

Brooks, T. 1967: A study of corticolous Myxomycetes. Ph.D. Dissertation, Univ. Kansas. - 244 pp. Lawrence.

Davis, E. \& Butterfield, W. 1967: Myxomycetes cultured from the peel of banana fruit. - Mycologia 59: 935-937.

Eliasson, U. 1975: Myxomycetes in the nature reserve of the Gothenburg Botanical Garden. - Svensk Bot. Tidskr. 69: 105-112.

Eliasson, U. \& Strid, А. 1976: Wood-inhabiting fungi of alder forests in North-Central Scandinavia 3. Myxomycetes. - Bot. Notiser 129: 267-272.

Eliasson, U. \& Sunhede, S. 1972: Some Swedish records of Myxomycetes. - Svensk Bot. Tidskr. 66: 18-24.

Emoto, Y. 1977: The Myxomycetes of Japan. - 263 pp. Tokyo.

Farr, M. 1976: Flora Neotropica 16. Myxomycetes, - 304 pp. New York.

Gilbert, H. \& Martin, G. 1933: Myxomycetes found on bark of living trees. - Univ. Iowa Stud. Nat. Hist. 15: 3-8.

Gray, W. \& Alexopoulos, C. 1968: Biology of the Myxomycetes. - 288 pp. New York.

Hintikka, T. 1919: Révision des Myxogastres de Finlande. - Acta Soc. Fauna Flora Fennica 46 (9): 3-43.

Härkönen, M. 1974: Über die finnischen Schleimpilzen. Karstenia 14: 54-81.

- " - 1977: Corticolous Myxomycetes in three different habitats in southern Finland. - Karstenia 17: 19-32.

," - 1978a: On corticolous Myxomycetes in northern Finland and Norway. - Ann. Bot. Fennici 15: 32-37.

- " 1978b: A new species of Myxomycetes, Physarum apiculosporum, described and cultivated. - Karstenia 18: $24-26$. 
Karlsen, A. 1934: Studies on Myxomycetes 1. New records for Norway. - Bergens Mus. Arbok, Naturvidensk. Rekke 1: $1-8$.

- " - 1943: Studies on Myxomycetes 2. The Myxomycetflora of Hardanger. - Bergens Mus. Årbok, Naturvidensk. Rekke 2: $1-34$.

Karsten, P. 1876: Symbolae ad Mycologiam fennicam 3. Medd. Soc. Fauna Flora Fennica 1: 55-59.

Keller, H. \& Braun, L. 1977: Myxomycetes of Mexico 2. Bol. Soc. Mex. Mic. 11: 167-180.

Keller, H. \& Brooks, T. 1973: Corticolous Myxomycetes 1: Two new species of Didymium. - Mycologia 65: $286-294$.

Kowalski, D. 1975: The Myxomycete taxa described by Charles Meylan. - Mycologia 67: 448-494.

Lister, A. 1901: On the cultivation of Mycetozoa from spores. - J. Bot. 39: 5-8.

- " - 1911: A monograph of the Mycetozoa. 2nd ed., revised by G. Lister. - 302 pp., 200 pls. London.

- " - 1925: A monograph of the Mycetozoa. 3rd ed., revised by G. Lister. - 296 pp., 222 pls. London.

Martin, G. \& Alexopoulos, C. 1969: The Myxomycetes. 560 pp. Iowa City.
Mitchell, D. 1977: Kentish Myxomycetes. - Trans. Kent Field Club 6: $91-100$.

Nannenga-Bremekamp, N. 1966: Notes on Myxomycetes 11. Some new species of Stemonitis, Comatricha, Badhamia, Physarum, Diderma and Didymium. Proc. K. Nederl. Akad. Wetenschappen (C) 69: $350-363$.

- " - 1972: Notes on Myxomycetes 18. A new Didymium and some comments on the Didymium spcies with longstalked sporangia. - Proc. K. Nederl. Akad. Wetenschappen (C) 75: 352-363.

- " - 1974: De nederlandse myxomyceten. - 440 pp. Zutphen.

Rostafiński, J. 1875: Śluzowce (Mycetozoa) monografia. 432 pp., 13 pls. Paryz

Santesson, R. 1964: Swedish Myxomycetes. - Svensk Bot. Tidskr. 58: 113-124.

de Tempe, J. 1963: The blotter method for seed health testing. - Proc. Int. Seed Test. Ass. 28: 133-151.

Ylimäki, A., Koponen, H., Hintikka, E.-L., Nummi, M., Niku-Paavola, M.-L., Ilus, T., \& Enari, T.-M. 1978: Sienien ja eräiden niiden muodostamien toksiinien esiintyminen suomalaisessa viljassa. - VTT Biotekn. Lab. Tiedonantoja 18: $1-42$.

Accepted for publication

on June 1, 1978 